\title{
SMOKING AMONG MACEDONIAN WORKERS FIVE YEARS AFTER THE ANTI-SMOKING CAMPAIGN
}

\author{
Jordan MINOV ${ }^{1}$, Jovanka KARADŽINSKA-BISLIMOVSKA ${ }^{1}$, Kristin VASILEVSKA ${ }^{2}$, Zlatka \\ NELOVSKA ${ }^{1}$, Snežana RISTESKA-KUC ${ }^{1}$, Sašo STOLESKI ${ }^{1}$, and Dragan MIJAKOSKI ${ }^{1}$ \\ Institute of Occupational Health - WHO Collaborating Center for Occupational Health and GA2LEN Collaborating \\ Center ${ }^{1}$, Institute of Epidemiology and Biostatistics', Skopje, R. Macedonia
}

\author{
Received in September 2011 \\ CrossChecked in September 2011 \\ Accepted in May 2012
}

\begin{abstract}
To assess the efficacy of nationwide anti-smoking campaign, we compared the findings of a study on worker smoking performed in 2005 with our latest cross-sectional study completed in 2010. It included 753 randomly selected workers, of whom 126 office, 108 construction, 93 agricultural, 97 petroleum refinery, 114 textile, 117 food processing workers, and 98 cleaners. Information was collected with a selfadministered questionnaire. The prevalence of current smokers among all workers was $35.4 \%$, ranging from $30.2 \%$ in office workers to $43.5 \%$ in construction workers. It did not significantly differ from the prevalence recorded in 2005 (35.4 \% vs. $36.8 \%$, respectively; $\mathrm{P}=0.441)$. Mean pack-years smoked among all smokers was $12.4 \pm 2.3$, ranging from 10.9 in administrative workers to 13.7 in agricultural workers. We did not find any significant difference in the prevalence of current smokers between male and female workers and between workers aged less or more than 40 years, as well as between workers of higher and lower education. The prevalence of ex-smokers was $10.5 \%$, ranging from $8.4 \%$ in construction workers to $12.1 \%$ in administrative workers, whereas the prevalence of passive smokers was $29.1 \%$, ranging from $26.2 \%$ in food processing workers to $32.9 \%$ in agricultural workers.

Our findings indicate that the prevalence of current and passive smokers has remained high regardless of the anti-smoking campaign and call for stricter implementation of anti-smoking regulations.
\end{abstract}

KEY WORDS: current smoker, ex-smoker, occupation, passive smoker, prevalence, tobacco smoke

Tobacco smoking takes an enormous toll on the global burden of disease (1-3). Its adverse health effects are attributable to approximately 2,500 toxins in the tobacco plant and approximately 4,000 substances in the tobacco smoke. At least 250 of these are harmful and more than 60 are known or suspected to cause cancer $(4,5)$.

As many epidemiological and clinical studies indicate, the adverse health effects related to tobacco smoke include heart disease, lung cancer, chronic obstructive pulmonary disease, as well as an increase in the number and severity of asthma attacks, increased susceptibility to lung infections (such as pneumonia and bronchitis), other breathing problems including cough, mucus production, chest discomfort, and reduced lung function $(4,6,7)$. In addition, despite controversial results of the studies that investigated joint effects of tobacco smoke and specific workplace exposure, the role of such interaction in health impairment could not be excluded (8-10). To prevent adverse health effects, governments worldwide increase tobacco taxes, regulate tobacco content, control tobacco import, issue tobacco warning labels, promote anti-tobacco education, programmes to quit smoking and smokeless life-style, encourage the use of stop-smoking drugs, restrict or ban tobacco 
advertising, sponsorships and promotions, ban smokeless tobacco products (such as chewing tobacco and snuff), and restrict or ban smoking in work and public places $(11,12)$. The Republic of Macedonia has adopted many of these anti-smoking activities such as the 2005 law restricting indoor smoking to separated rooms (13) and the 2008 law banning indoor smoking in all public buildings, workplaces, and public transportation (14).

The aim of our study was to see whether these activities had an effect on smoking among Macedonian workers by comparing the latest findings with a study performed in 2005.

\section{SUBJECTS AND METHODS}

This cross-sectional study was performed at the Institute for Occupational Health of the Republic of Macedonia, Skopje - WHO Collaborating Center and

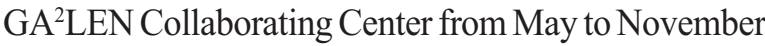
2010.

It included 753 randomly selected workers who completed the questionnaire ( $96.1 \%$ of all invited) from public administration, construction, agriculture, petroleum refining, textile industry, food processing, and cleaning). Three hundred eighty-nine were men and 364 women, aged 19 to 64 years (Table 1). All subjects gave informed consent to participate in the study.

\section{Questionnaire}

Information on smoking was collected using a self-administered questionnaire. Smoking was classified according to the World Health Organization (WHO) Guidelines for Controlling and Monitoring the Tobacco Epidemic (5). Current smoker was defined as a subject who smoked any tobacco product at the time of the survey. Daily smoker was defined as a current smoker who smoked at least once a day, except on days of religious fasting, while occasional smoker was defined as a current smoker who did not smoke every day. Daily smokers provided information on years of smoking and daily mean cigarettes smoked. From this information we calculated pack-years smoked (one pack-year denotes one year of smoking 20 cigarettes a day) using a website calculator designed by Masters and Tutt (16).

Ex-smoker was defined as a subject who used to smoke, but now does not smoke at all. Ex-smokers
Table 1 Demographics of the study subjects

\begin{tabular}{lc}
\hline $\begin{array}{l}\text { Sex, age, occupation, and level } \\
\text { of education }\end{array}$ & $\begin{array}{c}\text { Study subjects } \\
\text { (n=753) }\end{array}$ \\
\hline Men to women ratio & $1: 1$ \\
Age in years: Mean (range) & $38.7 \pm 12.9(19$ to 64) \\
Subjects aged $\leq \mathbf{4 0}$ years & $346(45.9)$ \\
Occupation & \\
Public administration & $126(16.7)$ \\
Construction & $108(14.3)$ \\
Agriculture & $93(12.4)$ \\
Petroleum refining & $97(12.9)$ \\
Textile industry & $114(15.1)$ \\
Food processing & $117(15.5)$ \\
Cleaning & $98(13.0)$ \\
Level of education & \\
High (University degree) & \\
Primary and secondary & $216(28.7)$ \\
education & $537(71.3)$ \\
\hline
\end{tabular}

Numbers (\%) are given, unless indicated otherwise.

were divided in those who quit smoking less than or more than two years ago).

Passive smoker was defined as a subject exposed to environmental tobacco smoke (ETS), that is, with at least one smoker in the household and/or the workplace $(17,18)$. In addition, passive smokers were divided in those who were exposed to ETS for less than or more than four hours per day.

\section{Statistical analysis}

For data description and analysis we used the Statistical Package for the Social Sciences (SPSS) version 11.0 for Windows. Continuous variables were expressed as mean values with standard deviation (SD) and nominal variables as numbers and percentages. The chi-square test was used for testing differences in prevalence. Pack-years smoked were compared using the independent-samples $t$-test. P-value below 0.05 was considered statistically significant.

\section{RESULTS}

The prevalence of the current smokers among all subjects was $35.4 \%$ (267 of 753 ), $94.4 \%$ (252 of 267) of whom were daily smokers. The prevalence of 


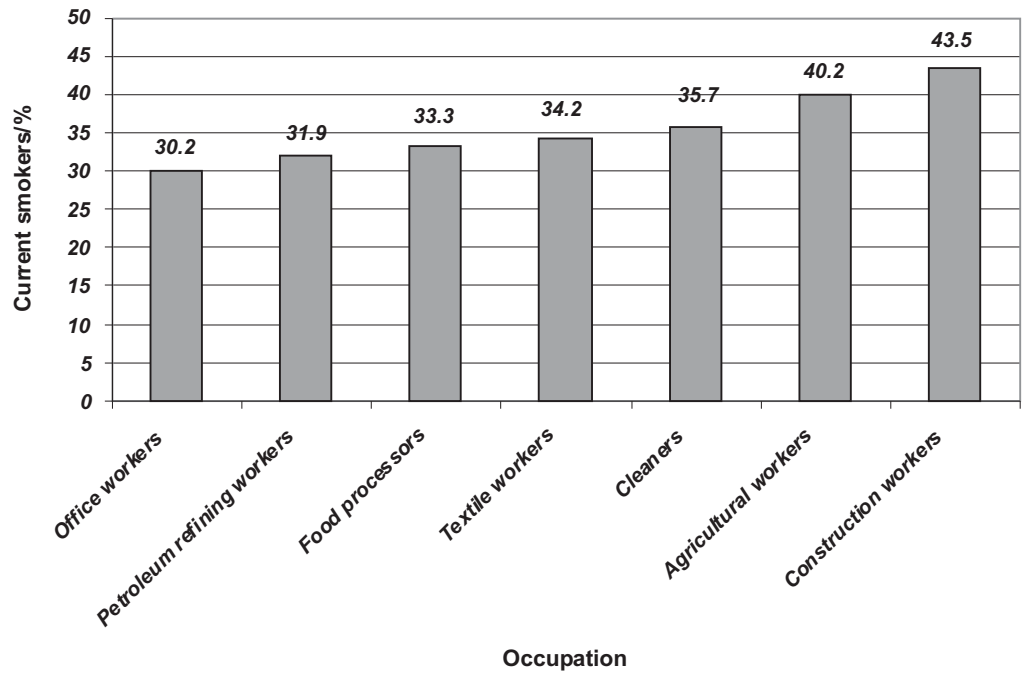

Figure 1 Distribution of current smokers by occupation

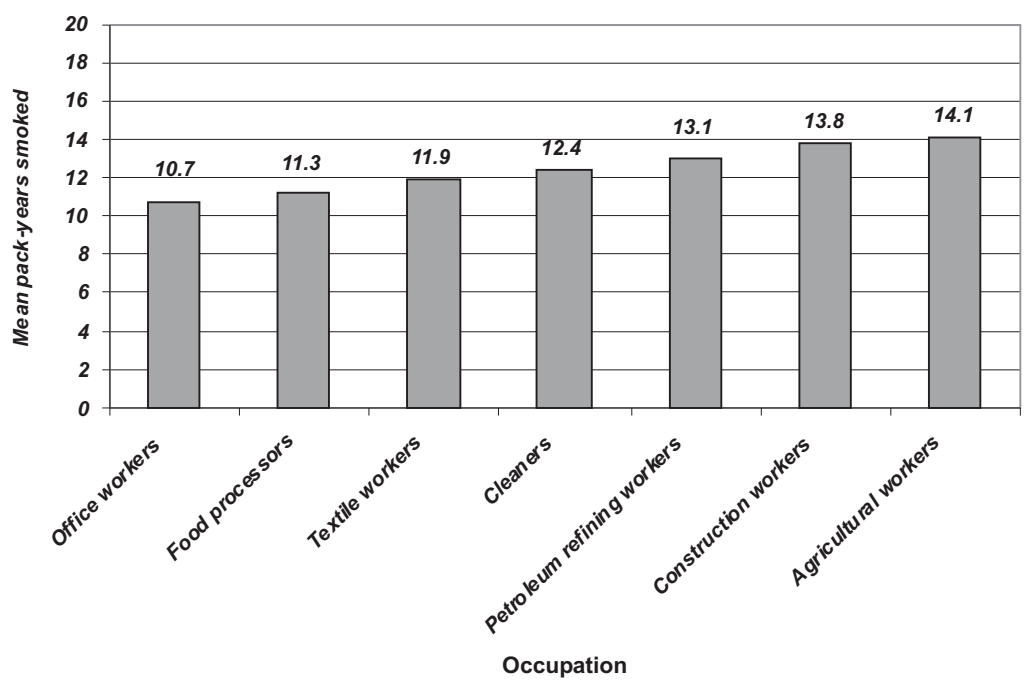

Figure 2 Distribution of daily smokers by pack-years smoked

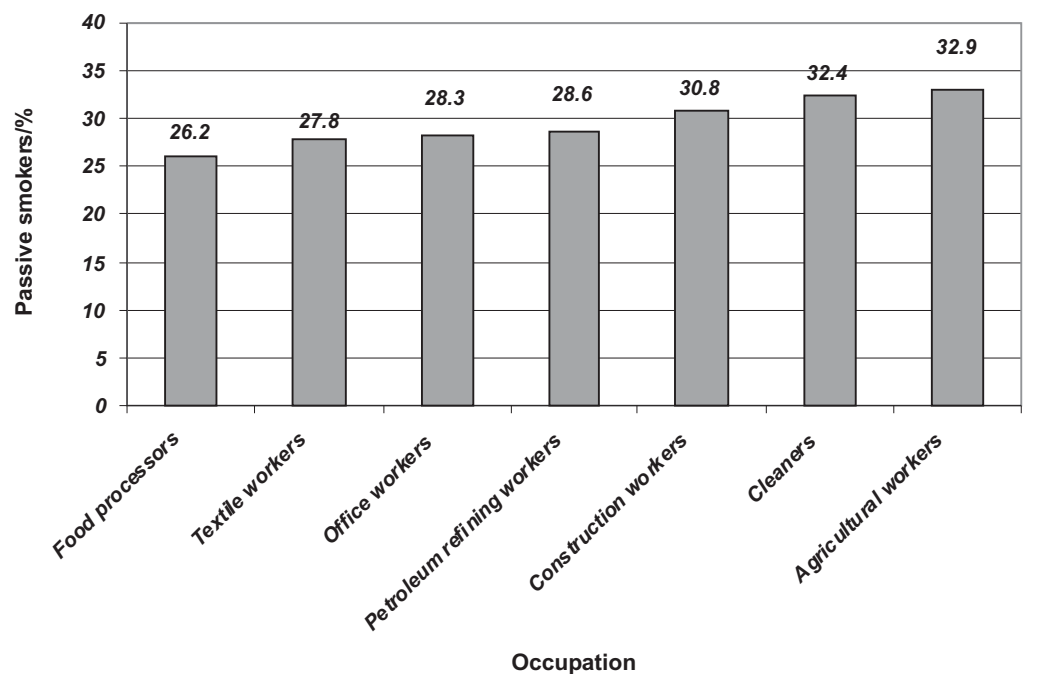

Figure 3 Distribution of ex-smokers by occupation 


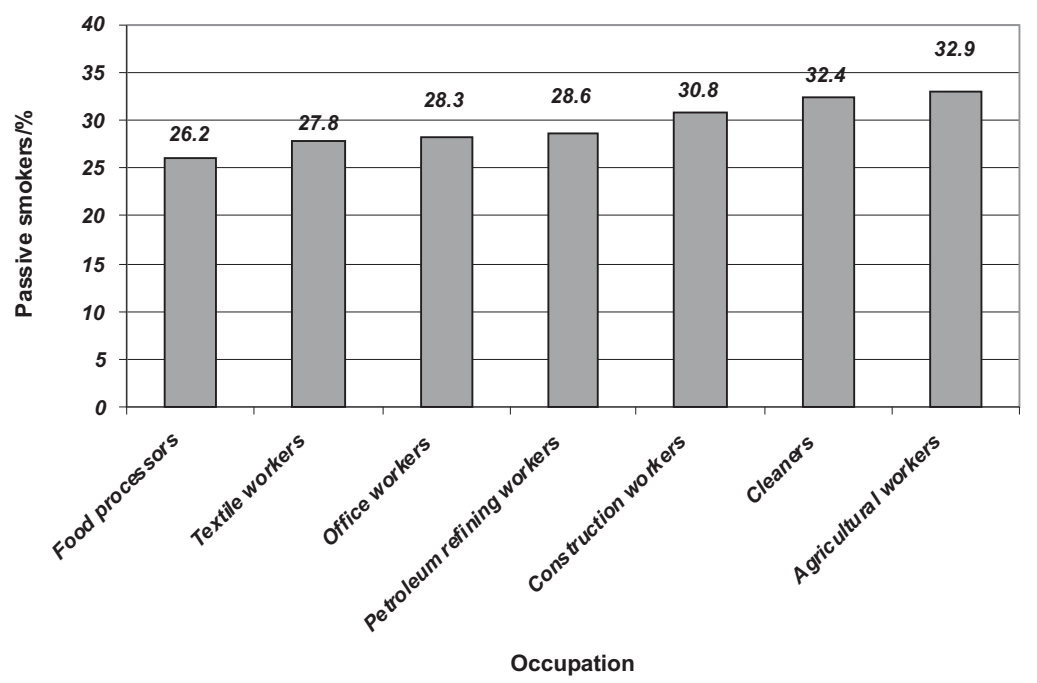

Figure 4 Distribution of passive smokers by occupation

current smokers ranged from $30.2 \%$ in office workers to $43.5 \%$ in construction workers. We found no significant difference between occupations (Figure $1)$.

This prevalence of current smokers is similar to the prevalence established in our study performed in 2005 ( $35.4 \%$ vs. $36.8 \%$, respectively, $\mathrm{P}=0.441$; chisquare test) (19).

Mean pack-years smoked in all daily smokers was $12.4 \pm 2.3$ (12.9 \pm 1.8 in men and $11.3 \pm 3.7$ in women), ranging from 10.7 in office workers to 14.1 in agricultural workers. Again, there was no significant difference between occupations (Figure 2).

Men and women did not differ significantly in the prevalence of current smokers $(38.6 \%$ vs. $33.7 \%$, respectively, $\mathrm{P}=0.344$; chi square test) and neither did subjects below 40 from those above 40 years of age ( $37.9 \%$ vs. $34.1 \%$, respectively, $\mathrm{P}=0.294$; chi square test). The prevalence of current smokers was lower in subjects with high (university) education than in subjects with lower education, but not significantly ( $29.6 \%$ vs. $40.8 \%$, respectively, $\mathrm{P}>0.05$, chi square test).

The prevalence of ex-smokers among all subjects was $10.5 \%$ (79 of 753 ), ranging from $8.4 \%$ in construction workers to $12.1 \%$ in office workers (Figure 3). Differences in the distribution of exsmokers by sex, age, and education level were not significant either.

The prevalence of passive smokers was $29.1 \%$ (219 of 753) among all subjects, ranging from $26.2 \%$ in food processing to $32.9 \%$ in agricultural workers (Figure 4). Differences in the distribution of passive smokers by occupation sex, age, education level, and years of exposure to ETS were not significant.

\section{DISCUSSION}

Between the studies performed in 2005 (19) and this one in 2010, the Macedonian government launched a broad anti-smoking campaign that included indoor smoking restriction and ban laws, educational programmes, promotion of smokeless life-style, tobacco warning labels, etc.. However, the comparison among the same occupations between these two years showed no decline in smoking.

As the prevalence of current smokers in this study is similar to its prevalence in the general Macedonian population (34.2\%) (20), we can compare our results with the US New Jersey Adult Tobacco Survey of the general population (21) and with the Australian National Health Survey in workers (22). These countries have come up with more effective antismoking strategies and achieved a significant decline in the prevalence of current smokers in both general population and worker populations over the last decade. Similarly effective have been the Slovenian tobacco control measures (23).

In our study, the prevalence of current smokers was the highest in construction and agricultural workers. Similar prevalence was reported for 
construction workers in the US study by Bang \& Kim (24), by the Centers for Disease Control (CDC) report for May 2003 (25), and by the Australian Bureau of Statistics Report for 2007-2008 (22). Unlike our study, these reports found a significant difference between construction workers and office workers.

Another indication of the success of anti-smoking campaigns is the prevalence of ex-smokers, which in our study $(10.5 \%)$ showed a minor increase with respect to 2005 (8.1\%) (19), whereas the CDC reported a much higher prevalence in certain occupations (e.g. public administration) reaching up to $20 \%(25)$.

The prevalence of passive or second-hand smokers in our study (29.1\%) remained similar to 2005 (31.5\%) (19) and 2007 (27.4 \%) (26). Most passive smokers of all occupations were exposed to ETS for less than four hours. In a longitudinal study in 12 European countries, Australia and the USA, Janson et al. (27) reported a drop in passive smoking between 1990 and 1994. They also found that people with lower education were more than twice as likely to be exposed to ETS and suggested that anti-smoking strategies should primarily target people with lower education. Our study has not confirmed these findings, as we found a similar prevalence of passive smokers across all occupations and educational levels.

There were some limitations to our study, which should be taken into account when interpreting the results. First, this survey is designed as a crosssectional study, instead of longitudinal, which renders comparison between this and the 2005 study somewhat imprecise. We could not perform a longitudinal study because of high worker turnover, construction and agriculture in particular. Second, five years is not long enough to evaluate the effects of an anti-smoking campaign, but may provide preliminary information. However, continuous monitoring of smoking in the working population may provide guidelines to better targeting and modifying anti-smoking programmes.

The strength of the study, on the other hand, is that it included all aspects of smoking (current, ex-, and passive smoking) in a large sample across several occupations.

In conclusion, our findings suggest that the antismoking campaign in Macedonia has left much to be desired and call for stricter enforcement of the adopted anti-smoking regulations and for additional activities that would target all workers and occupations to prevent adverse health effects of tobacco smoking.

\section{REFERENCES}

1. Kusma B, Scutaru C, Quarcoo D, Welte T, Fischer TC, Gronenberg-Kloft B. Tobacco control: visualisation of research activity using density-equlizing mapping and scientometric benchmarking procedures. Int J Environ Res Public Health 2009;6:1856-69.

2. Hatsukami DK, Stead LF, Gupta PC. Tobacco addiction. Lancet 2008;371:2027-31.

3. Yelin E, Katz P, Balmes J, Trupin L, Eamest G, Eisner M, Bianc P. Work life of persons with asthma, rhinitis, and COPD: a study using a national population-based sample. J Occup Toxicol 2006;1:2.

4. Haustein KO. Tobacco constituens and additives. In: Haustein KO, editor. Tobacco or health. Springer: Berlin Heidelberg; 2001.

5. Secondary smoke. [displayed 21 July 2011]. Available at: http://www.cancer.org.

6. Alipour S, Deschamps F, Lesage F-X. Effects of environmental tobacco smoke on respiratory symptoms and pulmonary function. Inhal Toxicol 2006;18:569-73.

7. Centers for Disease Control and Prvenetion (CDC). Smokingattributable mortality, years of potential life lost, and productivity losses - United States, 2000-2004. MMWR Morb Mortal Wkly Rep 2008;57:1226-8.

8. Minov J, Karadzinska-Bislimovska J, Vasilevska K, RisteskaKuc S, Stoleski S. Bronchial hyperresponsiveness in workers exposed to organic dusts: effect of smoking. Allergy Hypersensitivity Asthma 2006;4:11-20.

9. Ho SY, Lam TH, Chung SF, Lam TP. Cross-sectional and prospective associations between passive smoking and respiratroy symptoms at the workplace. Ann Epidemiol 2007;17:126-31

10. Minov J, Karadzinska-Bislimovska J, Vasilevska K, RisteskaKuc S, Stoleski S. Effects of passive smoking at work on respiratory symptoms, lung function, and bronchial responsiveness in never-smoking office cleaning women. Arh Hig Rada Toksikol 2009;60:327-34.

11. Two-phase antismoking strategy [displayed 21 July 2011]. Available at http://www.guide2.co.nz/politics/news/twophase-anti-smoking-strategy/11/17431

12. Fan W, Pin J,Li B. Anti-smoking Campaign in China: An Inevitable War [displayed 21 July 2011]. Available at http:// www2.gsu.edu/ $\sim$ wwwdcm/cime/Antismoking_Wu_Fan Jiang Pin Bai_Li.pdf

13. Закон за заштита од пушење [Law for protection of smoking, in Macedonian]. Official Gazette of R. Macedonia $37 / 2005$.

14. Закон за измени и дополнувања на Законот за заштита од пушењето [Law for amendments and supplements to the Law for protection of smoking, in Macedonian]. Official Gazette of R. Macedonia 103/2008, 140/08.

15. World Health Organization (WHO). Guidelines for controlling and monitoring the tobbaco epidemic. Geneva: WHO; 1998.

16. Smoking Pack-Years [displayed 21 July 2011]. Available at http://smokingpackyears.com/

17. U.S. Department of Health and Human Services. The health consequences of smoking: chronic obstructive pulmonary disease. A report of the Surgeon General. DHHS Publication No. 84-50 205, 1984 
18. Janson C, Chinn S, Jarvis D, Zock JP, Toren K, Burney P, for the European Community Respiratory Health Survey. Effects of passive smoking on respiratory symptoms, bronchial responsiveness, lung function, and total serum $\operatorname{IgE}$ in the European Community Respiratory Health Survey: a crosssectional study. Lancet 2001;358:2103-9.

19. Minov J, Karadzinska-Bislimovska J, Vasilevska K, Stoleski $\mathrm{S}$. Пушачки статус ка изложени и неизложени работници [Smoking status in exposed and unexposed workers, in Macedonian]. Mak Med Pregled 2006;60:128.

20. Minov J, Cvetanov V, Karadzinska-Bislimovska J, Ezova N, Milkovska S, Risteska-Kuc S. Epidemioloski karakteristiki na bronhijalnata astma vo R. Makedonija [Epidemiological characteristics of bronchial asthma in R. Macedonia, in Macedonian]. Mak Med Pregled 2003;56:156.

21. Tobacco Surveillance Data Brief: Adult Cigarette Smoking Prevalence [displayed 21 July 2011]. Available at http:// www.state.nj.us/health/as/ctcp/documents/adult cigarette_smoking_prevalence_brief.pdf

22. South Australian smoking prevalence by industry and occupation [displayed 21 July 2011]. Available at http://www. cancersa.org.au/cms_resources/200910_Smoking prevalence_by_industry_occupation.pdf
23. Slovenian Coalition for Tobacco Control [18 January 2012]. Available at: http://www.uicc.org/membership/sloveniancoalition-tobacco-control

24. Bang KM, Kim JH. Prevalence of cigarette smoking by occupation and industry in the United States. Am J Ind Med 2001;40:233-9.

25. Work-related lung disease surveillance system. Volume 1. Smoking Prevalence by Industry and Occupation [displayed 31 May 2012]. Available at: http://www2.cdc. gov/drds/WorldReportData/SectionDetails.asp?ArchiveID= 1\&SectionTitleID=17.

26. Minov J, Karadzinska-Bislimovska J, Vasilevska K, RisteskaKuc S, Stoleski S. Exposure to environmental tobacco smoke in the workplace in Macedonia: where are we now? Arh Hig Rada Toksikol 2008;59:103-9.

27. Janson C, Künzli N, de Marco R, Chinn S, Jarvis D, Svanes C, Heinrich J, Jögi R, Gislason T, Sunyer J, AckermannLiebrich U, Anto JM, Cerveri I, Kerhof M, Leynaert B, Luczynska C, Neukrich F, Vermiere P, Wjst M, Burney P. Changes in active and passive smoking in the European Community Respiratory Health Survey. Eur Respir J 2006;27:517-24. 


\section{Sažetak}

\section{PUŠENJE MEĐU MAKEDONSKIM RADNICIMA PET GODINA NAKON KAMPANJE PROTIV} PUŠENJA

Želeći utvrditi djelotvornost kampanje protiv pušenja u Makedoniji, usporedili smo rezultate istraživanja o pušenju u radničkoj populaciji provedenog 2005. s rezultatima našega najnovijega presječnoga randomiziranog ispitivanja koje je dovršeno 2010. Ispitivanje je obuhvatilo 753 radnika, od kojih je 126 uredskih, 108 građevinskih, 93 poljoprivrednih, $97 \mathrm{u}$ rafineriji nafte, 114 tekstilnih, 117 prehrambenih te 98 čistač(ic)a. Podaci su prikupljeni s pomoću upitnika koji su ispunjavali ispitanici. Prevalencija aktivnih pušača među svim radnicima bila je $35,4 \%$, od $30,2 \%$ u uredskih radnika do $43,5 \%$ u građevinskih. Nije se značajno razlikovala od prevalencije zabilježene 2005. (35,4\% odnosno $36,8 \%, \mathrm{P}=0,441)$. Srednja

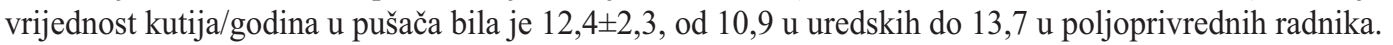
Značajnih razlika u aktivnome pušenju nije bilo među ženama i muškarcima, radnicima starijim i mlađima od 40 godina, niti među radnicima višeg i nižeg obrazovanja. Prevalencija bivših pušača bila je 10,5 \%, od $8,4 \%$ u građevinskih do $12,1 \%$ u uredskih radnika, dok je prevalencija pasivnih pušača bila $29,1 \%$, od $26,2 \%$ u radnika u preradi hrane do $32,9 \%$ u poljoprivrednih radnika.

Naši rezultati pokazuju da je prevalencija aktivnih i pasivnih pušača ostala visoka bez obzira na kampanju protiv pušenja te pozivaju na strožu provedbu propisa koji ograničavaju pušenje.

KLJUČNE RIJEČI: aktivni pušač, bivši pušač, duhanski dim, pasivni pušač, prevalencija, zanimanje

\section{CORRESPONDING AUTHOR:}

Dr Jordan B. Minov

Department of Cardiorespiratory Functional Diagnostics Institute of Occupational Health of R. Macedonia, Skopje WHO Collaborating Center and $\mathrm{GA}^{2} \mathrm{LEN}$ Collaborating Center

II Makedonska Brigada 43, 1000 Skopje, R. Macedonia E-mail:minovj@hotmail.com 